\title{
Man-in-the-barrel syndrome as an atypical form of Amyotrophic Lateral Sclerosis
}

\author{
Síndrome do Homem do Barril como forma atípica de Esclerose Lateral Amiotrófica
}

\author{
Marco Orsini' ${ }^{1}$, Marcos RG de Freitas ${ }^{2}$, Mariana P Mello 3 , Osvaldo JM \\ Nascimento ${ }^{4}$, Carlos Henrique Melo Reis ${ }^{5}$
}

\section{SUMMARY}

The "Man-in-the-barrel syndrome" makes reference to a picture of bilateral brachial muscular weakness, which incapacitates the patients in functional activities with upper limbs elevation. Since its description, there are several cases described of patients with this syndrome, whose etiology differs from the first one described. We read the article by Sasaki et al. "Atypical form of amyotrophic lateral sclerosis: a new term to define a previously well-known form of ALS" (2000), concerning the atypical form of amyotrophic lateral sclerosis (ALS). The pattern of muscular atrophy in these patients differed from that of typical ALS in that severe muscle involvement was confined to the upper limbs, predominantly the proximal portion and shoulder girdle.

Keywords: Amyotrophic Lateral Sclerosis. Neuromuscular Diseases. Anterior Horn Cells. Motor Neuron Disease.

Citation: Orsini M, de Freitas MRG, Mello MP, Nascimento OJM, Melo Reis $\mathrm{CH}$. Man-in-the-barrel syndrome as an atypical form of Amyotrophic Lateral Sclerosis.

\begin{abstract}
RESUMO
A síndrome do "Homem do Barril" faz referência a um quadro de fraqueza muscular braquial bilateral, a qual incapacita os pacientes em atividades funcionais com a elevação dos membros superiores. Desde sua descrição, existem alguns casos de pacientes com tal síndrome, de etiologias variadas. Realizamos a leitura do artigo de Sasaki et al. "Atypical form of amyotrophic lateral sclerosis: a new term to define a previously well-known form of ALS" (2000), a respeito de uma distribuição atípica da Esclerose Lateral Amiotrófica (ELA). O quadro de atrofia muscular nesses pacientes difere da típica ELA, devido ao envolvimento confinado nos membros superiores, predominantemente no terço proximal e cintura escapular.
\end{abstract}

Unitermos: Esclerose Amiotrófica Lateral. Doenças Neuromusculares. Células do Corno Anterior. Doença dos Neurônios Motores.

Citação: Orsini M, de Freitas MRG, Mello MP, Nascimento OJM, Melo Reis $\mathrm{CH}$. Síndrome do Homem do Barril como forma atípica de Esclerose Lateral Amiotrófica.
Research was made in Neuromuscular Disease Outpatient Division, Departament of Neurology at Federal Fluminense University, Niterói, RJ, Brazil.

1. Undergraduate in Medicine, Associate Professor of Neurologic Rehabilitation and Scientific Initiation, Escola Superior de Ensino Helena Antipoff (ESEHA), Department of Neurology, Federal Fluminense University - UFF, Niterói, RJ.

2. MD, PhD, Chair of Neurology and Head of Staff, Department of Neurology, UFF, Niterói, RJ.

3. Physical Therapist, Program of Scientific Initiation, Neurology Department, UFF, Niterói, RJ.

4. MD, PhD, Chair of Neurology, Department of Neurology, UFF, Niterói, RJ.

5. Chair of Neurology, Department of Neurology, Valença University of Medicine, Valença, RJ.
Endereço para correspondência: Marco Orsini Rua Prof. Miguel Couto 322/1001 24230-240 Niterói, RJ

E-mail: orsini@predialnet.com.br 
Amyotrophic lateral sclerosis (ALS) is a progressive and fatal illness that affects the upper and lower motor neurons (pyramidal tracts and the anterior horn of the spinal cord). The depletion of the motor units provokes countless deficiencies/incapacities that cause damages related to daily activities. We read with interest the article by Sasaki et al. ${ }^{1}$ concerning the atypical form of ALS. The pattern of muscular atrophy in these patients differed from that of typical ALSin that severe muscle involvement was confined to the upper limbs, predominantly the proximal portion and shoulder girdle, sparing the face and the legs until late in the disease's course or until the terminal stage.

We like to emphasize that although such presentation is not so usual, we present in our service patients with subsequent diagnosis of ALS according to criteria established for the El Escorial, that initiated the clinical picture with characteristics similar to the above mentioned study, mimicking the "man-in-the-barrel syndrome" (MBS). In one of our cases, a 55-year-old man, merchant retired, relates that approximately 2 years ago began a pattern marked by motor deficiencies in third distal of the left upper limb that quickly compromised both arms, incapacitating him to carry out determined functional activities. He also perceived that when walking the arms were positioned backwards and did not accompany the steps. He noticed subsequentlythat therightshoulderpresentedacadaveric aspect. He did not refer weakness in lower limbs. Theneurologicalexamshowedgeneralizedatrophy in upper limbs associated to weakness. Fasciculations were present in the scapular girdle. Pyramidalsignswerealso found (hyperactivedeepreflexes and bilateral Babinski signal). The sensibility was normal. The electroneuromyography registered, in therest,abnormalelectrophysiologicalelementsin the researched muscles, such as fasciculations and positive waves. Aftervoluntaryvolumetric contraction weregotten tracings composed by motor units action potentials of abnormal morphology, with motor units recruitment standard of the rarefied kind of theexplored muscles, resulted suggestive of compromise of the anterior horn of spinal cord. He received the diagnosis of ALS, second the criteria of the El Escorial, after the association of signals of compromise of the previous anterior horn and of the pyramidal tract, without compromise of the sensibility. The complementary exams confirmed the clinical finds.
The MBS makes reference to a picture of bilateral brachial muscular weakness, with proximalpredominance, whichincapacitatesthepatients in functional activities with upper limbs elevation. Since its description, there are several cases described of patients with this syndrome, whose etiology differs from the first one described. The patient is unable to move his arm to any stimulus, appearing as if the upper limbs are confined within a barrel ${ }^{2}$. It was originally attributed to cerebral infarctions in the watershed zones between the middle and anterior cerebral arteries distributions ${ }^{3}$. However, other pathophysiologicprocesseslocalizing tothecerebral cortex, pons, anterior horn cells of cervical spinal cord, for example in ALS and spinal muscular atrophies, and even the peripheral nerves may also produce this phenotype ${ }^{4,5}$.

Progressive amyotrophy that is isolated to the upper limbs in an adult often suggests ALS. The fact that weakness can remain largely confined to the arms for long periods of time in individuals presenting with this phenotype has not been emphasized ${ }^{5}$.

Dide, in 1917, initially described the bilateral paralysis of the upper limbs (brachial diplegia) ${ }^{6}$. It has been attributed to a variety of further clinical conditions, suchaspolyneuropathy,motoneurondiseases, central pontine myelinolysis, ischemia of the anterior horns during septicemia, cervical epidural infection and, cervical spinal cord ischemia ${ }^{5,7,8}$. In 1970, Bell used the term "cruciate paralysis" to describe paralysis of both arms, caused by injury of the upper portion of the pyramidal decussation in three patients ${ }^{9}$. In their paper, cause was a fracture of the odontoid process with a complete dislocation of the upper fragment in the first patient, hyperextension cervical spine injury in the second, and in the coexistence of a basilar impression and acute hydrocephalus following suboccipital craniectomy for removal of a meningeoma of the posterior fossa in the third.

Mohr, in 1969, coined the term "distal field infarction"todescribeborderzoneinfarctscaused by systemic hypoperfusion or carotid obstruction, brachial paresis being the predominant clinical symptom of the latter ${ }^{10}$.

Sageprospectivelyexamined34comatosepatients who had suffered systemic hypoperfusion of various causes ${ }^{11}$. He found paresis of both arms in 11 of these patients, and introduced the term MBS for the syndrome description. This description illustrates the clinical aspect of the patient who seems to have the upper part of his body stuck in a barrel, 
while maintaining mobility of the lower limbs and the face ${ }^{12}$. Since this report, MBS has been described following cardiac surgery both in the presence and in the absence of systemic hypoperfusion, following cardio-respiratoryarrest, inassociation with bilateral hemorrhagic contusion of the inferior frontal lobes after closed head injury, brain metastasis, and finally infarction of the central spinal cord after unilateral vertebral artery dissection ${ }^{4,13}$. The pathology of brachial diplegia is secondary to superficial anterior junctional infarcts, which concern the border zone between the area of the anterolateral cerebral artery and the central cerebralarteryand whichare responsible for lesions of the precentral gyrus, the motor region for the arm and shoulder. When the damage is bilateral, as occurs in cases of systemichypofusion, it is responsible for brachial diplegia. The deficiency may be global or predominantly distal or proximal. There are no repercussions on the motricity of the face or of the lower limbs, and either deep or superficial sensitivity ${ }^{2,13}$. Deep tendon reflexes are sharp because of damage to the pyramidal pathways ${ }^{13}$.

MBS has also been reported secondary to brain involvementotherthan watershedinfarctions: metastatic disease and closed head injury ${ }^{14}$. MBS may also due to pontine lesions ${ }^{5}$. In spinal cord involvement there are cases reported of infarction of thespinalcord, upperspine injuries, and cervicalepidural infection ${ }^{15}$. The motor neurons of the cervical cord may be involved, as in ALS, or in lower motor neurons disease (LMND) ${ }^{7}$. In these second disorders the arms are completely paralyzed with normality of the lower limbs.

Sometimes there is involvement of both the brachial plexus as in rare cases of bilateral amyotrophicneuralgia ${ }^{16}$. The prognosis of theseprocesses usually is negative in its majority; cause the gravity of the etiological process ${ }^{16}$, like in ALS, with a mortality of up to $90 \%$ in some series ${ }^{11}$.

However, there are cases of survival with total recovery or with persistence of a discrete distal deficiency, with suggest that the prognosis in terms of survival or functional impairment depends directly on the severity and the duration of the systemic hypoperfusion, as well as the quality and rapidity of the treatment of the causes of the low blood flow ${ }^{12}$.

\section{CONCLUSION}

In many cases MBS is due to a serious cerebral hypoperfusion that secondarily originates bilateral ischemic infarcts in the bordering territories between the anterior and medium cerebral arteries, in the areas responsible for the brachial motility. There are other cases where this syndrome is due to cerebral metastases, hemorrhagic contusion by craniocerebral trauma, involvement of the pons, medulla and the cervical spinal cord as in ALS and LMND. Although the etiology of the MBS is varied, the prognosis of this syndrome is not benign in many cases. It is important to emphasize that some cases of motor neuron disease may be characterized by unusual muscular atrophy restricted to the upper limbs, especially in the proximal portion and the shoulder girdle, with a variable clinical course which may progress to bulbar involvement. The patients with suchanatypical patterncould becategorizedas ALS or a subtype of ALS.

\section{REFERENCES}

1.Sasaki S, Gamez J, Cervera C, Codina A. Atypical form of amyotrophic lateral sclerosis: a new term to define a previously well known form of ALS. J Neurol Neurosurg Psychiatr 2000;68:118-9. 2.Sasaki S, Makoto I. Atypical form of amyotrophic lateral sclerosis. J Neurol Neurosurg Psychiatr 1999;66:581-5.

3.Wahl CC. "Man-in-the-Barrel” Syndrome After Endoscopic Sinus Surgery. Anesth Analg 1998;87:1196-8.

4.Sage Jl. "Man in the barrel" syndrome after cerebral hypoperfusion: clinical description, incidence, and prognosis. Ann Neurol 1983;14:131

5.Crisostomo EA, Suslavich FJ. Man-in-the-barrel syndrome associated with closed head injury. J Neuroimaging 1994;4:116-7.

6.Alberca R, Iriarte LM, Rasero P, Villalobos F. Brachial diplegia in central pontine myelinolysis. J Neurol 1985;231:345-6.

7.Dide $M$, Lhermite J. La diplegie brachiale spasmodique consecutive aux blessures par coups de feu de la region cervicale. Progres Med 1917;1:1-3.

8.Katz JS, Wolfe GI, Andersson PB, Saperstein DS, Elliott JL, Nations $\mathrm{SP}$, et al. Brachial amyotrophic diplegia: a slowly progressive motor neuron disorder. Neurology 1999;53:1071-6.

9.Bell HS. Paralysis of both arms from injury of the upper portion of the pyramidal decussation: 'cruciate paralysis'. J Neurosurg 1970;33:376-80

10.Mohr JP. Distal field infarction. Neurology 1969;12:279.

11.Sage Jl, Van-Uitert RL. Man-in-the-barrel syndrome. Neurology 1986;36:1102-3.

12.Clerget L, Lenfant F, Roy $H$, Giroud $M$, Salem DB, Freysz $M$. Man-in-the-Barrel Syndrome after Hemorrhagic Shock. J Trauma 2003;54:183-6.

13. Hurley JP, Wood AE. Isolated man-in-the-barrel syndrome following cardiac surgery. Thorac Cardiovasc Surg 1993;41:252-4.

14.Deleu D, Salim K, Mesraoua B, Siddig AE, Hail HA, Hanssens Y. "Man-in-the-barrel" syndrome as delayed manifestation of extrapontine and central pontine myelinolysis: Beneficial effect of intravenous immunoglobulin. J Neurol Sci 2005;237:103-6.

15.Berg D, Müllges W, Koltzenburg M, Bendszus M, Reiners K. Manin-the-barrel syndrome caused by cervical spinal cord infarction. Acta Neurol Scand 1998;97:417-9.

16.Luengo-Álvarez J, Ramírez-Moreno JM, Falcón-García A, Casado-Narajo I. Neuralgia amiotrófica bilateral y simétrica que simula el síndrome del 'hombre en el barril'. Rev Neurol 2006;43:123-4. 